\title{
PENDIDIKAN MULTIKULTURAL UNTUK MENINGKATKAN KUALITAS PEMBELAJARAN IPS DI SEKOLAH DASAR
}

\author{
Sudrajat \\ Pendidikan IPS Fakultas Ilmu Sosial UNY \\ Email: sudrajat73@gmail.com, Hp.085743430029
}

\begin{abstract}
Abstrak
Penelitian ini bertujuan untuk mengetahui peningkatan kualitas Pembelajaran IPS di SD melalui Pendidikan Multikultural. Penelitian ini dilakukan dengan menggunakan metode penelitian tindakan kelas (PTK), model Kemmis \& Taggart yang terdiri dari: planning (perencanaan), acting \& observing (pelaksanaan dan pengamatan), serta reflecting (refleksi). Tindakan penelitian dilakukan dengan tiga siklus dimana pada siklus pertama tindakan yang dilakukan adalah dengan menerapkan model pembelajaran jigsaw, pada siklus kedua dengan model team games tournament, sedangkan pada siklus ketiga dengan model team investigation report. Subjek penelitian adalah siswa kelas V SD Negeri 2 Kadipiro, Ngestiharjo, Kasihan, Bantul. Teknik pengumpulan data menggunakan wawancara dan observasi. Analisis data menggunakan model analisis interaktif yang dikembangkan oleh Miles \& Huberman yaitu data reduction, data display, dan conclusion atau kesimpulan. Hasil Penelitian menunjukkan bahwa; 1) siklus pertama pola perancangan upaya peningkatan meningkatkan kerjasama seluruh siswa, 2) siklus kedua pada pola penanaman sikap kerjasama dan kompetisi, 3) siklus ketiga pada cara siswa melakukan investigasi, merumuskan hipotesis, dan menyelesaikan permasalahan yang muncul.
\end{abstract}

Kata kunci: Pendidikan Multikultural, Kualitas Pembelajaran, IPS di SD. 


\begin{abstract}
This research aims to determine the improvement of quality learning of socizal studies in elementary school through Multicultural Education. The study was conducted by classroom action research (PTK), by Kemmis \& Taggart models consisting of planning (planning), acting and observing (execution and observation), as well as reflecting (reflection). The treatments of the research conducted by three cycles in which the first cycle of the action taken is to implement jigsaw learning model, the second cycle model with team games tournament, and the third cycle model by investigation team report. Subjects of research were fifth grade students of SD Negeri 2 Kadipiro, Ngestiharjo, Kasihan, Bantul. The technique of collecting data both use of interviews also observations. Analysis of data using interactive models developed by Miles \& Huberman, include of data reduction, data display, and conclusion. The research showed: 1) the first cycle of design patterns improve efforts to increase cooperation among all students, 2) second cycle on planting patterns of cooperation and competition attitudes, 3) the third cycle students conduct investigations, formulation, hypotheses, and resolve problems.
\end{abstract}

Keywords: Multicultural Education, Quality of Education, Elementary social studies.

\title{
Pendahuluan
}

Realitas bahwa bangsa Indonesia terdiri dari berbagai macam etnis, agama, bahasa, adat, dan kebiasaan telah muncul sejak lama dan menjadi agenda permasalahan yang sangat kompleks. Lihat saja peristiwa-peristiwa di Aceh, Sampit, Sambas, Ambon, dan daerah lain dimana benturan antar kelompok dengan ikatan primordial yang fanatis dan membabi buta telah memakan korban jiwa dan harta benda. Benturan antar budaya, antar ras, etnik, agama dan nilai-nilai yang terjadi di masyarakat pada muaranya akan mengancam integritas dan ketahanan bangsa Indonesia. Sejalan dengan hal tersebut, tidak berlebihan apabila kita sebagai masyarakat multikultur mewaspadai benturan antar peradaban (clash of civilization) sebagaimana dikemukakan oleh Samuel $\mathrm{P}$ Huntington. 
Lunturnya kepribadian nasional dikalangan generasi muda, juga menjadi permasalahan lain yang tidak kalah penting. Derasnya arus informasi global yang berdampak pada penetrasi budaya asing memiliki pengaruh yang signifikan terhadap pola pikir, sikap dan perilaku generasi muda. Di lingkungan generasi muda persoalan tersebut dapat dilihat pada kurang berkembangnya sikap kemandirian, kreativitas serta produktivitas, sehingga generasi kita kurang dapat berpartisipasi secara maksimal dalam proses membangun karakter bangsa. Dampak negatif yang dapat dirasakan secara langsung adalah penyalahgunaan narkoba dan zat adiktif lainnya (NAPZA), tawuran pelajar, mahasiswa, kriminalitas, minuman keras, penyebaran penyakit HIV / AIDS dan lainnya.

Permasalahan tersebut apabila tidak memperoleh perhatian dan penanganan secara bijaksana dan sistematis, akan memiliki dampak yang lebih luas dan dapat mengganggu kesinambungan dan kestabilan dalam Pembangunan Nasional. Muara dari segala kekhawatiran kita tersebut adalah ancaman terhadap integrasi bangsa yang semakin terbuka lebar.

Bila kita amati, agama seharusnya dapat menjadi pendorong bagi umat manusia untuk selalu menegakkan perdamaian dan meningkatkan kesejahteraan bagi seluruh umat di bumi ini. Namun, realitanya agama justru menjadi salah satu penyebab terjadinya kekerasanan dan kehancuran umat manusia. Oleh karena itu, diperlukan upaya preventif agar masalah pertentangan agama tidak akan terulang lagi di masa yang akan datang. Misalnya, dengan mengintensifkan forum dialog antar umat beragama dan aliran kepercayaan (dialog antar iman), membangun pemahaman keagamaan yang lebih pluralis dan inklusif, dan 
memberikan pendidikan tentang pluralisme dan toleransi beragama melalui lembaga pendidikan.

Dalam kaitan dengan permasalahan tersebut, pendidikan merupakan salah satu entry point untuk mengurainya. Pendidikan merupakan elemen penting dari kehidupan seseorang karena merupakan aspek strategis bagi suatu negara yang terkait langsung dengan penyediaan sumber daya manusia (SDM) berkualitas sebagai penggerak utama pembangunan dalam perwujudan nation and character building. Pendidikan diselenggarakan secara demokratis dan berkeadilan serta tidak diskriminatif dengan menjunjung tinggi hak asasi manusia, nilai keagamaan, nilai kultural, dan kemajuan bangsa. Dalam lingkup kehidupan Nasional Pendidikan kita ditandai oleh kondisi yang bersifat multikultural. Praktik pendidikan di Indonesia selama ini cenderung menekankan pada aspek kompetisi, sehingga melahirkan individu-individu yang bersifat individualis bahkan egois (Suyato, 2006).

Dipandang sangat penting untuk memberikan porsi pendidikan multikultural sebagai wacana baru dalam sistem pendidikan di Indonesia terutama agar peserta didik memiliki kepekaan dalam menghadapi gejala-gejala dan masalah-masalah sosial yang berakar pada perbedaan kerena suku, ras, agama dan tata nilai yang terjadi pada lingkungan masyarakatnya sebagai salah satu penguat integrasi kebangsaan. Hal ini dapat diimplementasikan baik pada substansi maupun model pembelajaran yang mengakui dan menghormati keanekaragaman budaya, untuk memberikan pembekalan dan membantu perkembangan wawasan pemikiran dan kepribadian serta melatih kepekaan peserta didik dalam menghadapi gejala-gejala dan 
masalah-masalah sosial yang terjadi pada lingkungan masyarakatnya.

Pada hakekatnya pendidikan multikultural bermakna untuk mempersiapkan seluruh siswa bekerja secara aktif menuju kesamaan struktur dalam organisasi dan lembaga sekolah. Pendidikan multikultural bukanlah kebijakan yang mengarah pada pelembagaan pendidikan dan pengajaran inklusif lewat kurikulum yang berperan bagi kompetisi budaya individual. Selain itu, pembelajaran berbasis multikultural berusaha memberdayakan siswa untuk mengembangkan rasa hormat kepada orang yang berbeda budaya, memberi kesempatan untuk bekerja bersama dengan orang atau kelompok orang yang berbeda etnis atau rasnya secara langsung.

Pendidikan IPS adalah program pendidikan yang membina peserta didik agar menjadi warga negara yang baik dalam suasana kedamaian. Indikatornya, setelah peserta didik mempelajari IPS, akan memiliki sejumlah kompetensi yaitu berkomunikasi, beradaptasi, bersinergi dengan baik dan selalu berpikir positif terhadap orang lain (Saidiharjo, 2004). Penerapan IPS di sekolah dasar dimaksudkan bahwa bahan kajian ilmu sosial seperti geografi, sejarah, ekonomi, sosiologi diintegrasikan ke dalam berbagai topik ke beberapa mata pelajaran. Integrasi tersebut difokuskan dengan memusatkan pembelajaran pada suatu masalah yang dibahas, dikaji dan dipecahkan melalui berbagai bahan dari beberapa mata pelajaran. Proses pembelajaran terpadu merupakan kegiatan pembelajaran yang menyeluruh dan sistematis.

Langkah dalam proses pembelajaran dengan pendekatan terpadu adalah memilih tema yang dapat menjadi awal topik untuk memadukan beberapa mata pelajaran, melakukan peta 
konsep untuk menemukan konsep yang terkait dalam mata pelajaran dan memilih aktifitas belajar yang memungkinkan adanya keterpaduan (Depdikbud, 1996).

Untuk itu melalui pendekatan multikultural dalam pembelajaran IPS diharapkan mampu meningkatkan partisipasi siswa dalam melakukan rekomendasi nilai-nilai lokal serta membangun cara pandang kebangsaan. Dari kemampuan ini, siswa memiliki keterampilan mengembangkan kecakapan hidup dalam menghormati budaya lain, toleransi terhadap perbedaan, akomodatif, terbuka dan jujur dalam berinteraksi dengan orang lain yang berbeda suku, agama etnis dan budayanya, memiliki empati yang tinggi terhadap perbedaan budaya lain, dan mampu mengelola konflik dengan tanpa kekerasan (conflict non violent). Strategi cooperative learning yang akan digunakan berfungsi untuk menandai adanya perkembangan kemampuan siswa dalam belajar bersama-sama mensosialisasikan konsep IPS dan nilai budaya lokal dari daerahnya untuk belajar bersama orang lain dalam satu komunitas.

\section{Pendidikan Multikultural}

Pendidikan multikultural diselenggarakan dalam upaya mengembangkan kemampuan siswa dalam memandang kehidupan dari berbagai perspektif budaya yang berbeda dengan budaya yang mereka miliki, dan bersikap positif terhadap perbedaan budaya, ras, dan etnis. (Farris \& Cooper, 1994). Pendidikan multikultural merupakan strategi pendidikan yang memanfaatkan keberagaman latar belakang kebudayaan dari peserta didik sebagai salah satu kekuatan untuk membentuk sikap multikultural. Strategi ini sangat bermanfaat, sekurangkurangnya bagi sekolah sebagai lembaga pendidikan dapat membentuk pemahaman bersama atas konsep kebudayaan, 
perbedaan budaya, keseimbangan, dan demokrasi dalam arti yang luas (Liliweri, 2005).

Sementara itu Hilda Hernandez (Choirul Mahfud, 2010: 196) mengemukakan dua definisi klasik yaitu: pertama, menekankan esensi pendidikan multikultural sebagai perspektif yang mengakui realitas politik, sosial dan ekonomi yang dialami oleh masingmasing individu dalam pertemuan manusia yang kompleks dan beragam (plural) secara kultur, kedua, pendidikan multikultural merupakan sebuah empowering yaitu pendidikan yang selayaknya dan seharusnya bisa untuk semua anak didik. Pendidikan multikultural menyoal tentang etnisitas, gender, kelas, bahasa, agama, dan perkecualian yang mempengaruhi, membentuk, dan mempola tiap-tiap individu sebagai makhluk budaya. Dalam konteks yang luas, pendidikan multikultural membantu menyatukan bangsa secara demokratis dengan menekankan pada perspektif pluralitas masyarakat di berbagai bangsa, etnik, dan kelompok budaya yang berbeda.

Banks (Skeel, 1995) menyatakan bahwa tujuan pendidikan yang berbasis multikultural dapat diidentifikasi seperti berikut: memfungsikan peranan sekolah dalam memandang keberadaan siswa yang beraneka ragam, membantu siswa dalam membangun perlakuan yang positif terhadap perbedaan kultural, ras, etnik, kelompok keagamaan, memberikan ketahanan siswa dengan cara mengajar mereka dalam mengambil keputusan dan keterampilan sosialnya, membantu peserta didik dalam membangun ketergantungan lintas budaya dan memberi gambaran positif kepada mereka mengenai perbedaan kelompok.

Banks (1993) mendiskripsikan evolusi pendidikan multibudaya dalam empat fase. Pertama, ada upaya untuk mempersatukan kajian etnis pada setiap kurikulum. Kedua, hal ini diikuti oleh 
pendidikan multietnis sebagai usaha untuk menerapkan persamaan pendidikan melalui reformasi keseluruhan sistem pendidikan. Ketiga, kelompok marginal yang lain, seperti perempuan, orang cacat, homo dan lesbian, mulai menuntut perubahan-perubahan mendasar dalam lembaga pendidikan. Keempat, perkembangan teori, riset dan praktek, perhatian pada hubungan antar ras, kelamin, dan kelas telah menghasilkan tujuan bersama bagi kebanyakan ahli, jika bukan para praktisi, dari pendidikan multibudaya. Gerakan reformasi mengupayakan transformasi proses pendidikan dan lembaga-lembaga pendidikan pada semua tingkatan sehingga semua murid, apapun ras atau etnis, kecacatan, jenis kelamin, dan kelas sosial akan menikmati kesempatan yang sama untuk menikmati pendidikan.

James Banks menjelaskan bahwa pendidikan multikultural memiliki beberapa dimensi yang saling berkaitan satu dengan yang lain, yaitu: Pertama, Content Integration, yaitu mengintegrasikan berbagai budaya dan kelompok untuk mengilustrasikan konsep mendasar, generalisasi dan teori dalam mata pelajaran/disiplin ilmu. Kedua, The Knowledge Construction Proces, yaitu membawa siswa untuk memahami implikasi budaya kedalam sebuah mata pelajaran (disiplin). Ketiga, An Equity Paedagogy, yaitu menyesuaikan metode pengajaran dengan cara belajar siswa dalam rangka memfasilitasi prestasi akademik siswa yang beragam baik dari segi ras, budaya (culture) ataupun sosial (social). Keempat, Prejudice Reduction, yaitu mengidentifikasi karakteristik ras siswa dan menentukan metode pengajaran mereka. Kemudian, melatih kelompok untuk berpartisipasi dalam kegiatan olahraga, berinteraksi dengan seluruh staff dan siswa yang berbeda etnis dan ras dalam upaya menciptakan budaya 
akademik yang toleran dan inklusif (James A. Banks, 2000: 22022).

Berdasarkan keempat strategi pembelajaran di atas, pola pembelajaran berbasis multikultural dilakukan untuk meningkatkan kesadaran diri siswa terhadap nilai-nilai keberbedaan dan keberagaman yang melekat pada kehidupan siswa lokal sebagai faktor yang sangat potensial dalam membangun cara pandang kebangsaan untuk menguatkan kembali intagritas bangsa.

Dengan kesadaran diri siswa terhadap nilai-nilai lokal, siswa diharapkan memiliki ketegaran dan ketangguhan secara pribadi, juga mampu melakukan pilihan rasional (rational choice) ketika berhadapan dengan isu-isu lokal, nasional dan global. Siswa mampu menatap perspektif global sebagai suatu realitas yang tidak selalu dimaknai secara emosional, akan tetapi juga rasional serta tetap sadar akan jati diri bangsa dan negaranya. Kemampuan akademik tersebut, salah satu indikasinya ditampakkan oleh siswa dalam perolehan hasil pembelajaran yang dialami.

\section{Pembelajaran IPS di Sekolah Dasar}

Pengertian Pendidikan Ilmu Sosial adalah program pendidikan yang memanfaatkan ilmu-ilmu sosial untuk tercapainya tujuan pendidikan. Contohnya pendidikan geografi, pendidikan sejarah, pendidikan ekonomi, pendidikan kewarganegaraan, pendidikan sosiologi, dan sebagainya (Saidiharjo, 2004).

Pengertian Ilmu Pengetahuan Sosial yang dalam literature asing dikenal dengan social studies yang dapat diartikan sebagai penelaahan tentang masyarakat. Ilmu Pengetahuan Sosial (Social Studies) menurut Mayhood dkk., (1991: 10), adalah "The Social Studies are comprissed of those aspests of history, geography, and 
pilosophy which in practice are selected for instructional purposes in schools and collengs"

Pendidikan IPS merupakan pendidikan yang mengembangkan pengetahuan, sikap dan ketrampilan sosial dalam rangka membentuk pribadi warga negara yang baik dan merupakan program pendidikan sosial pada jalur pendidikan sekolah (Udin, 2004). Pembelajaran IPS Terpadu dirancang secara sistematis tujuannya untuk meningkatkan pemahaman dan penanaman sikap siswa. Di dalam proses pembelajaran banyak melibatkan peran aktif antara guru dengan siswa, sesuai dengan tujuan pembelajaran yang disampaikan oleh guru melalui materi, metode, media dan evaluasi pembelajaran.

Ellis (1997: 6) menjelaskan hakikat pembelajaran IPS sebagai berikut "social studies is the area of the curriculum dedicated to the study of human beings, it lends it self quite naturally to the care and nurturing of the individual child". Maksudnya bahwa lingkup wilayah IPS dalam kurikulum diabadikan pada pembelajaran umat manusia secara alami menjaga dan mengembangkan karakter dan pribadi anak. Jadi, Pembelajaran IPS merupakan pembelajaran yang menyangkut segala aspek hubungan dalam kehidupan manusia.

Esensi tujuan pembelajaran IPS adalah perubahan perilaku dan tingkah laku positif siswa sesuai dengan budaya, nilai, kebiasaan dan tradisi yang berlaku di dalam masyarakatnya. Dalam penelitian ini lebih mengarah pada tercapaianya pola sikap pada diri siswa untuk saling menghormati, menghargai, toleransi terhadap budaya lain. Sehingga output dari pembelajaran IPS Terpadu melalui pendidikan multikultural dapat mencapai proses belajar mengajar yang aktif dan lebih bermakna. 
Dengan pembelajaran yang berbasis multikultural diharapkan dapat membawa perubahan dari budaya yang berfokus pada guru menuju budaya pembelajaran yang berfokus pada siswa. Pendidikan Ilmu Pengetahuan Sosial (IPS) di SD harus memperhatikan kebutuhan anak yang berusia antara 6-12 tahun. Anak dalam kelompok usia 7-11 tahun menurut Piaget (1963) berada dalam perkembangan kemampuan intelektual atau kognitifnya pada tingkatan kongkrit operasional.

Mereka memandang dunia dalam keseluruhan yang utuh, dan menganggap tahun yang akan datang sebagai waktu yang masih jauh. Yang mereka pedulikan adalah sekarang (kongkrit) dan bukan masa depan yang belum bisa mereka pahami (abstrak). Padahal bahan materi IPS penuh dengan pesan-pesan yang bersifat abstrak. Konsep-konsep seperti waktu, perubahan, kesinambungan (continuity), arah mata angin, lingkungan, ritual, akulturasi, kekuasaan, demokrasi, nilai, peranan, permintaan, atau kelangkaan adalah konsep-konsep abstrak yang dalam program studi IPS harus dibelajarkan kepada siswa SD.

Berbagai cara dan teknik pembelajaran dikaji untuk memungkinkan konsep-konsep abstrak itu dipahami anak. Bruner (1978) memberikan pemecahan berbentuk jembatan bailey untuk mengkongkritkan yang abstrak itu dengan enactive, iconic, dan symbolic melalui percontohan dengan gerak tubuh, gambar, bagan, peta, grafik, lambang, keterangan lanjut, atau elaborasi dalam kata-kata yang dapat dipahami siswa. Itulah sebabnya IPS SD bergerak dari yang kongkrit ke yang abstrak dengan mengikuti pola pendekatan lingkungan yang semakin meluas (expanding environment approach) dan pendekatan spiral dengan memulai dari yang mudah kepada yang sukar, dari yang sempit menjadi lebih luas, dari yang dekat ke yang jauh, dan seterusnya. 
Pendidikan IPS di Sekolah Dasar juga harus ada upaya mengubah paradigma pembelajaran IPS yang cenderung berorientasi kognitif menuju IPS yang berorientasi pada afektif dan psikomotor. Pendekatan pembelajaran yang bersifat kognitif telah terbukti menghasilkan intelektual yang tidak peduli dengan nilai, sikap dan kultur masyarakatnya.

Dalam pembelajaran IPS perlu dilakukan perencanaan pembelajaran yang dituangkan dalam RPP karena seperti dikatakan oleh Sergiovanni dalam Syaiful Sagala (2009: 56) “plans are guides, approximations, goal post, and compass setting not irrevocable commitments or decision commandements".

Kerangka pikir penelitian ini dapat digambarkan sebagai berikut:

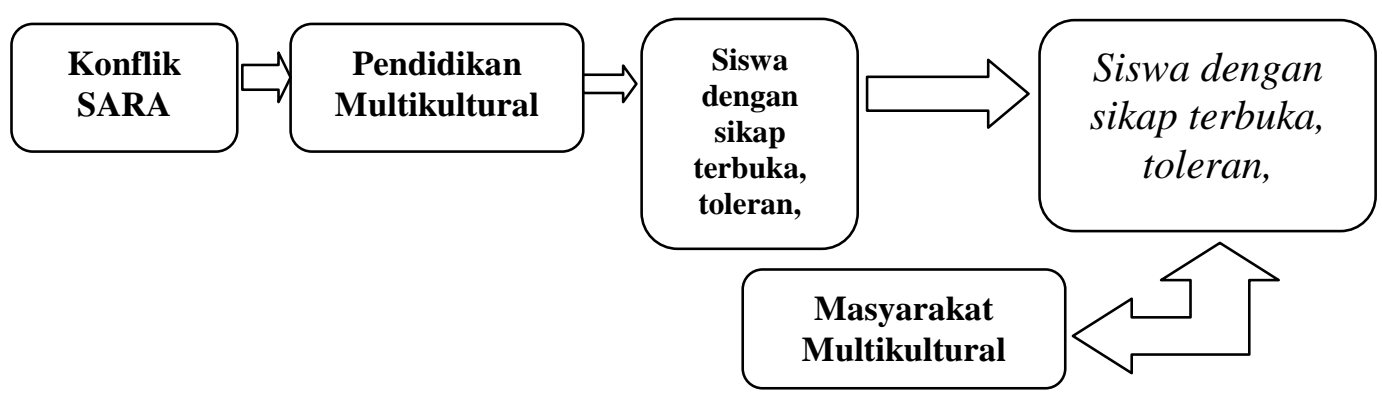

Gambar 1. Kerangka pikir penelitian

\section{Metode Penelitian}

Penelitian ini dilakukan dengan menggunakan metode penelitian tindakan kelas (PTK). Model yang diacu dalam penelitian ini adalah model yang dikembangkan oleh Kemmis \& Taggart (1982: 14) yang terdiri dari planning (perencanaan), acting \& observing (pelaksanaan dan pengamatan), serta reflecting (refleksi). Tindakan penelitian dilakukan dengan tiga siklus dimana pada siklus pertama tindakan yang dilakukan adalah dengan menerapkan model pembelajaran jigsaw, pada siklus kedua 
dengan model team games tournament, sedangkan pada siklus ketiga dengan model team investigation report.

Subjek penelitian siswa kelas V SD Negeri 2 Kadipiro yang beralamat di Kadipiro, Ngestiharjo, Kasihan Bantul. Sedangkan waktu penelitian dilakukan sekitar 5 bulan mulai bulan April sampai bulan Agustus 2010. Teknik pengumpulan data dengan menggunakan wawancara, observasi. Wawancara dilakukan dengan bertanya langsung kepada responden, sedangkan observasi melalui pengamatan langsung pada objek yang diteliti yaitu guru dan siswa.

Untuk menganalisis data selama di lapangan peneliti menggunakan model analisis interaktif yang dikembangkan oleh Miles \& Huberman (1984: 21) yaitu data reduction, data display, dan conclusion atau kesimpulan.

\section{Hasil dan Pembahasan}

Cooperative learning merupakan strategi belajar mengajar yang menekankan sikap atau perilaku bersama dalam bekerja atau membantu diantara sesama dalam struktur kerja sama yang teratur dalam kelompok yang terdiri dari dua orang atau lebih. Strategi ini menempatkan siswa dalam sebagai bagian dari sistem kerja sama dalam mencapai hasil belajar yang optimal, mendorong kemampuan siswa dalam memecahkan masalah yang ditemui selama pembelajaran dan merumuskan alternatif pemecahan masalah pada materi yang dihadapi. Penelitian ini dilakukan selama tiga siklus, setiap siklus diberikan treatment yang berbeda dalam mengimplementasikan pendidikan multikultural dalam pembelajaran IPS di sekolah dasar.

Dalam siklus pertama, kegiatan pembelajaran dirancang pada upaya meningkatkan kerjasama siswa dalam memahami materi pembelajaran. Kerjasama siswa dapat dilihat dari sikap siswa 
dalam menerima penjelasan dari temannya sebagai upaya mendiseminasi hasil belajar kepada sesama siswa. Dalam pengamatan tim peneliti, terlihat bagaimana siswa menghargai teman, menerima masukan teman, dan saling mendengarkan tanpa memandang latar belakang keyakinan, suku, rasial dan prototype primordial teman lainnya. Sikap seperti diatas penting untuk ditumbuhkembangkan dalam masyarakat multikultur seperti di kelas V SD Negeri 2 Kadipiro tersebut. Di samping itu siswa juga terlihat antusias mengikuti kegiatan pembelajaran sehingga suasana kelas menjadi lebih positif dan lebih bermakna. Metode pembelajaran yang diterapkan di siklus pertama antara lain diskusi kelompok.

Dalam siklus kedua, sikap yang ingin ditanamkan oleh tim peneliti adalah kerjasama dan kompetisi. Dalam kehidupan seharihari siswa dituntut untuk bekerjasama dan berkompetisi dengan teman lain, sehingga kompetisi yang sehat dan kerjasama yang sehat perlu ditumbuhkembangkan terutama pada anak usia sekolah dasar. Karena pada anak usia sekolah dasar sangat memungkinkan untuk perkembangan karakter dan sikap. Dalam pengamatan peneliti, suasana kelas menjadi lebih ramai terutama pada saat lomba cerdas cermat. Sorakan dan ejekan kadangkadang terdengar ketika kelompok mereka menjawab benar atau salah, tetapi tetap terkendali sehingga pembelajaran dapat berjalan dengan lancar.

Dalam hal terlihat siswa dapat berkompetisi secara sehat dan fair, sebuah sikap dan suasana yang sangat dibutuhkan dalam kehidupan sehari-hari. Selain itu, sikap kerjasama juga Nampak dalam diri siswa, dari mulai memecahkan masalah, mencari jawaban dari berbagai pertanyaan, dan kompak dalam menjawab 
secara benar dan cepat. Sikap ini yang dapat dikembangkan dalam diri anak untuk melatih saling kerjasama dan berkompetisi.

Dalam siklus ketiga, kegiatan pembelajaran berlangsung lebih lama, bahkan waktunya harus ditambah sehingga membutuhkan tiga kali pertemuan. Suasana kelas menjadi lebih hidup dimana siswa bekerja dalam kelompok untuk melakukan investigasi (pencarian data awal), merumuskan hipotesis, dan menyelesaikan permasalahan yang muncul. Dengan bimbingan guru, siswa dapat menemukan data-data untuk menyelesaikan permasalahan yang muncul. Siswa belajar dengan cara membangun pengetahuannya sendiri sedikit demi sedikit, hasilnya diperluas melalui konteks yang terbatas, sehingga pembelajaran menjadi lebih bermakna. Berbeda dengan siklus sebelumnya, siklus ketiga lebih menekankan pada berpikir kritis siswa melalui diskusi kelompok. Siswa diminta mencari permasalahan, siswa pula yang mencari solusi dari permasalahan yang ditemuinya. Hal ini melatih siswa untuk peka terhadap berbagai hal yang terjadi di masyarakat, dan mampu memahami dampak yang ditimbulkan dari permasalahan serta menentukan solusi yang tepat.

Menurut guru kolaborator (Diana), kegiatan pembelajaran yang telah dilakukan dengan strategi cooperative learning merupakan strategi pembelajaran yang baru dilaksanakan pertama kalinya dalam pembelajaran IPS. Selama ini guru selalu mengajar dengan metode ceramah, yang kadang-kadang dipadukan dengan tanya jawab atau brain storming. Hal ini menyebabkan siswa jenuh, sehingga timbul kesan bahwa pembelajaran IPS membosankan. Guru hanya menekankan aspek kognitif cenderung verbalisme, sehingga timbul kesan IPS sulit, bahkan lebih sulit dari pelajaran matematika. 
Dengan strategi pembelajaran yang baru tersebut, siswa menjadi lebih antusias dan memiliki motivasi belajar yang lebih tinggi. Singkat kata dalam pandangan Diana, strategi cooperative learning telah meningkatkan kualitas pembelajaran IPS di kelasnya. Sejalan dengan pandangan Diana, kepala sekolah (Suharso) mengakui bahwa strategi pembelajaran yang diterapkan oleh peneliti telah memberikan kontribusi terhadap upaya menumbuh kembangkan sikap-sikap yang sangat diperlukan dalam masyarakat multikultur seperti menghargai, toleransi, mau mendengarkan, bekerjasama, dan kompetisi. Melalui pendekatan tersebut ketrampilan sosial siswa menjadi berkembang hal mana dapat dilihat dari kegiatan siswa selama proses belajar mengajar. Pendekatan cooperative learning juga berhasil meningkatkan kualitas pembelajaran IPS di kelas V SDN 2 Kadipiro Yogyakarta.

Dalam pandangan Suharso, hal tersebut perlu dikembangkan di sekolah dan ditindaklanjuti di lingkungan tempat tinggal siswa masing-masing sehingga sekolah dapat menjadi laboratorium bagi pengembangan kehidupan masyarakat multikultur yang sehat dan harmonis dalam suasana keterbukaan, positive-thinking, dan saling menghargai. Di samping itu, strategi yang diterapkan juga melatih siswa dalam meningkatkan kemampuan berkomunikasi secara verbal. Dengan demikian, siswa terbiasa berkomunikasi verbal secara santun dalam mengemukakan ide atau gagasannya.

Jadi, pendekatan cooperative learning dapat dijadikan model pembelajaran dalam pendidikan multikultural. Sejauh ini, pendidikan multikultural memang belum menemukan bentuk yang ideal dan kadang-kadang kurang jelas. Oleh karena itu, strategi pembelajaran ini perlu diujicobakan sebagai model pendidikan multikultural, di samping terus mencari format pendidikan multikultur lain yang lebih baik. Dengan demikian, 
pendidikan multikultur dapat diimplementasikan dalam pembelajaran IPS dengan strategi cooperative learning.

Pendidikan multikultural menghendaki penghormatan dan penghargaan setinggi-tingginya terhadap harkat dan martabat manusia, hal yang menjadi tujuan utama dalam pembelajaran IPS. Sangat relevan dengan tujuan pendidikan IPS, bahwa tujuannya untuk membentuk warga Negara yang baik. Indikatornya adalah mampu berinteraksi, berkomunikasi, berpikir positif, terbuka, jujur dan mampu menyelesaikan setiap persoalan. Dimana tujuan pembelajaran IPS hendak dicapai dalam proses pembelajaran baik di dalam kelas maupun di luar kelas.

Pendidikan multikultural dalam pembelajaran IPS berhasil di integrasikan dalam proses pembelajaran melalui pendekatan cooperative learning, dimana pendekatan ini menuntut siswa untuk memecahkan masalah secara berkelompok, dan mengkomunikasikan dalam rangka mencari solusi atau jawaban dari pertanyaan yang ditemui. Implementasi pendidikan multikultural melalui pendekatan Cooperative learning berhasil untuk meningkatkan kualitas pembelajaran IPS.

Guru sebagai fasilitator dan mediator sangat terbantu untuk mengimplementasikan pendidikan multikultural dalam pembelajaran. Melalui diskusi kelompok, banyak nilai yang dapat tertanam dalam diri siswa, misalnya kerjasama, berkompetisi secara sehat, menghormati, menghargai, tanggung jawab. Hal tersebut juga menjadi bagian dari implementasi pendidikan multikultural di sekolah, khususnya pembelajaran IPS.

\section{Simpulan}

Pendidikan Multikultural diselenggarakan dalam upaya mengembangkan kemampuan siswa dalam memandang kehidupan dari berbagai perspektif budaya yang berbeda dengan 
budaya yang mereka miliki, dan bersikap positif terhadap perbedaan budaya, ras, dan etnis. Pendidikan multikultural merupakan proses pengembangan seluruh potensi manusia yang menghargai pluralitas dan heterogenitasnya sebagai konsekwensi keragaman budaya, etnis, suku dan aliran (agama).

Pendidikan multikultural menghendaki penghormatan dan penghargaan setinggi-tingginya terhadap harkat dan martabat manusia, hal yang menjadi tujuan utama dalam pembelajaran IPS. Dalam penelitian ini lebih mengarah pada tercapaianya pola sikap pada diri siswa untuk saling menghormati, menghargai, toleransi terhadap budaya lain. Sehingga output dari pembelajaran IPS melalui pendidikan multikultural dapat mencapai proses belajar mengajar yang aktif dan lebih bermakna. Dengan pembelajaran yang berbasis multikultural diharapkan dapat membawa perubahan dari budaya yang berfokus pada guru (teacher centered) menuju budaya pembelajaran yang berfokus pada siswa (student centered).

\section{Daftar Pustaka}

Farris,P.J. \& Cooper, S.M. 1994. Elementary Social Studies: a Whole language Approach. Iowa: Brown\&Benchmark Publishers.

Liliweri, Alo. 2005. Prasangka \& Konflik: Komunikasi Lintas Budaya Masyarakat Multikultural. Yogyakarta. LKiS.

M.Ali. 2006. Menuju Multikutural Global. http://www2.kompas.com/kompas-cetak. diakses pada tanggal 3 Februari 2009

Miles, M.B \& Huberman, A.M. (1994). Qualitative Data Analysis. California: SAGE publication, Inc.

"Pameran Pendidikan Nasional Tahun 2002", www.asosiasipolitenik.or.id, diakses pada tanggal 30 Januari 2009. 
JIPSINDO No. 1, Volume 1, Maret 2014

Saidiharjo. 2004. Konsep Dasar Ilmu Pengetahuan Sosial (IPS). Yogyakarta: Program Pascasarjana UNY.

Singarimbun, Masri dan Sofian Efendi. 1982. Metode Penelitian Survai. Jakarta: LP3ES..

Skeel, D.J. 1995. Elementary Social Studies: Challenge for Tomarrow"s World. New York: Harcourt Brace College Publishers.

Sukardi. 2008. Metodologi Penelitian Pendidikan: Kompetensi dan Praktiknya. Jakarta: Bumi Aksara.

Sukardi, dkk. 2006. Pedoman Penelitian. Yogyakarta" Lembaga Penelitian UNY

Sugiyono. 2008. Metode Penelitian Pendidikan: Pendekatan Kuantitatif, Kualitatif, dan R\&D. Bandung: Alfabeta.

UU nomor 20 tahun 2003 tentang SISDIKNAS, (Bandung: Citra Utama, 2006).

Winataputra, Udin dkk (2004). Materi dan Pembelajaran IPS SD. Edisi kesatu Penerbit Universitas Terbuka. 